\title{
The use of amniotic membrane in the repair of duodenal wounds in Wistar rats ${ }^{1}$
}

\author{
Uso da membrana amniótica no reparo de feridas duodenais em ratos Wistar
}

\author{
Luciano Rodrigues Schimidt ${ }^{\mathrm{I}}$, Edson José Cardoso ${ }^{\mathrm{II}}$, Rogério Rodrigues Schimidt ${ }^{\mathrm{III}}$, Luiz Augusto Back ${ }^{\mathrm{IV}}$, Maria Beatriz Schiazawa ${ }^{\mathrm{V}}$, \\ Armando José d'Acampora" ${ }^{\text {II }}$ Monique Viana de Sousa ${ }^{\text {VII }}$

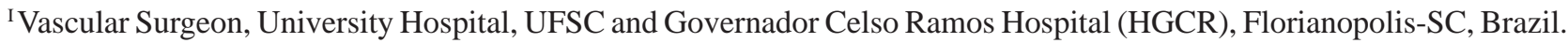 \\ ${ }^{\text {II }} \mathrm{PhD}$, Head Professor, Department of Surgery, UFSC, Chief of the Vascular Surgery Unit, UH, UFSC, Brazil.

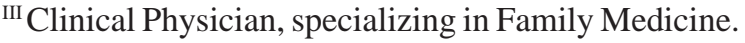 \\ Iv Vascular Surgeon, HGCR, Brazil. \\ ${ }^{v}$ Pathology Department, UFSC, Brazil. \\ ${ }^{\mathrm{VI}} \mathrm{PhD}$, Full Professor, Operative Technique, University of Southern Santa Catarina (UNISUL), Chief Surgeon of Florianopolis Hospital. \\ Brazil.

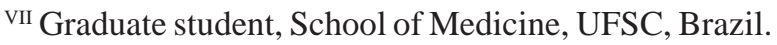

\begin{abstract}
Purpose: In the search of a new material to repair duodenal wounds, a trial was conducted to assess the behavior of human amniotic membrane in the repair of the duodenal wall in rats. Methods: Fifty Wistar rats weighing between 250 and $350 \mathrm{~g}$, male, were submitted to duodenotomy and randomly distributed into two groups. Group A $(n=8)$ had no treatment and was used as the control group. In Group B $(n=42)$ the duodenal wound was treated with a patch of human amniotic membrane. Results: All animals in Group A died. In Group B no changes were observed with regards to death or the formation of duodenal fistula. All animals presented peritoneal adherences in the region on the duodenal wall repair and intestinal obstruction was observed in two animals. Healing of the duodenal wall in the region of the patch took place progressively as the post-operatory period increased, with regeneration of the mucosa and of the smooth muscle layer. Conclusion: From the clinical standpoint, the amniotic membrane proved to be a biological tissue which served as a temporary seal and allowed the wound to heal by second-intention, with re-establishment of the duodenal wall structure.
\end{abstract}

Key words: Amnion. Duodenum. Biological Dressings. Rats.

\section{RESUMO}

Objetivo: Na busca de um novo material para o reparo dos ferimentos duodenais, foi efetuado um estudo para avaliar o comportamento da membrana amniótica humana no reparo da parede duodenal em ratos. Métodos: Foram utilizados 50 ratos Wistar, com peso entre 250 e $350 \mathrm{~g}$, machos, distribuídos, aleatoriamente, em dois grupos. Grupo A $(\mathrm{n}=8)$, submetido à duodenotomia sem tratamento, utilizados como controle. Grupo B ( $\mathrm{n}=42)$, submetido a um remendo de membrana amniótica humana para tratamento de ferimento duodenal provocado. Resultados: Todos os animais do grupo A foram a óbito. No grupo B não foram observadas alterações quanto a óbito ou formação de fístula duodenal. Observaram-se em todos os animais aderências peritoneais à região do reparo da parede do duodeno e obstrução intestinal em dois animais. O reparo da parede duodenal na área do remendo ocorreu de maneira progressiva com o aumento do período pós-operatório, com regeneração da mucosa e da camada muscular. Conclusão: A análise da membrana amniótica, do ponto de vista clínico, mostrou ser um tecido biológico que serviu para selar.

Descritores: Âmnio. Duodeno. Curativos Biológicos. Ratos.

${ }^{1}$ Research performed at Operative Technique and Experimental Surgery Laboratory (TOCE) Research Group, Federal University of Santa Catarina (UFSC), Brazil.

\section{Introduction}

Abdominal trauma is the most frequent cause of duodenal wounds, varying between 3 to $5 \%{ }^{1-4}$. The incidence of small bowel wounds has surpassed that of spleen and liver wounds, with a mortality rate of approximately $17 \% .^{5-7}$. In the clinical outcome of operated patients, with the utilization of several surgical techniques, the main complication is dehiscence of the intestinal suture with fistula formation, occurring in $2 \%$ to $16 \%$ of the cases $^{2,4,5,8,9}$. Intestinal obstruction on the duodenal repair spot is another important and frequent complication, with an incidence of $2 \%$ to $8 \%{ }^{1,9}$.

In order to avoid such complications, several authors have done research on materials and have perfected surgical tactics and 
techniques in search of a better surgical outcome in duodenal repair surgery $1,3,4,10,11$

The amniotic membrane is a physiological and biological coating, originated from the epiblastus which continues as the ectodermal surface in the fetus. It is an extension of the child's skin therefore it is the most physiological and biological membrane. Structurally speaking, the amnio-chorionic membrane is constituted by the epithelial face and the chorionic face ${ }^{12}$.

Barlas, in an experimental model using rabbits, described the growth of the neomucosa when lesions on the terminal ileum were closed with a patch of amniotic membrane. In humans, on the other hand, the amniotic membrane was used by Davis, who first reported its use as a skin substitute in the treatment of cutaneous wounds in the granulation phase ${ }^{13,14}$.

In the interest to find a new material to be used in the restoration of the duodenal wall, the human amniotic membrane presents features which seem to allow its use as a bioprosthetic material. It is easy to obtain and to store, has a low cost, nourishes itself through diffusion, has an angiogenic and a somewhat nonantigenic character, being relatively resistant to infection ${ }^{10}$.

Based on such data, we have decided to study the behavior of the human amniotic membrane in the restoration of the duodenal wall in rats.

\section{Methods}

Fifty rats were used ( $\mathrm{n}=50)$ Rattus novergicus, Rodentia Mammalia, of the Wistar strain, minimum age being 180 days, all male, weighing between 250 and $350 \mathrm{~g}$, originated from the Animal Facility at the Federal University of Santa Catarina (UFSC). The experiment was developed in the Operatory Technique and Experimental Surgery Laboratory (UFSC). and $\mathrm{B}$.

The animals were randomly distributed into two groups, A

Group A, comprised of eight animals, was used as the control group. Group B, comprised of 42 animals, on which the human amniotic membrane (AM) was used to treat the duodenal wound. It was divided into seven sub-groups of six animals, named B1, B3, $\mathrm{B} 5, \mathrm{~B} 7, \mathrm{~B} 14, \mathrm{~B} 21$ and $\mathrm{B} 28$, according to the respective time of euthanasia: $1^{\text {st }}, 3^{\text {rd }}, 5^{\text {th }}, 7^{\text {th }}, 14^{\text {th }}, 21^{\text {st }}$ and $28^{\text {th }}$ post-operatory days.

After the seven-day adaptation period, the animals remained in individual cages until the time predicted for euthanasia, being kept in adequate lighting, temperature and noise conditions. Free access to food and water was permitted, except for the 12 hours prior to surgery and the first 12 hours in the post-operatory period, during which they were fed an aqueous glucose solution at $5 \%$.

The animals were identified by numbers and weighed before the surgical procedure and every week four animals were operated on.

The amniotic membrane preserved in glutaraldehyde ${ }^{\circledR}$ was supplied by the LABCOR Laboratory from Belo Horizonte - MG. After opening the package containing the human amniotic membrane, preserved in glutaraldehyde ${ }^{\circledR}$, a fragment measuring 0.8 $\mathrm{x} 0.5 \mathrm{~cm}$ was prepared inside it and immersed for re-hydration in an aqueous solution of sodium chloride at $0.9 \%$, at room temperature, for 5 minutes.

The rats were submitted to general anesthesia through the inhalation of ethyl-ether, followed by the intramuscular administration of a ketamine and xylazine solution, in the respective doses of $35 \mathrm{mg} / \mathrm{Kg}$ and $5 \mathrm{mg} / \mathrm{Kg}$, on the inside of the left leg, for anesthetic maintenance. The animal was considered to be anesthetized upon loss of the corneal-palpebral reflex and when no motor response was displayed upon impingement of the fat pad on one of its paws. Fifty percent (50\%) of the initial dose was repeated when the animal still presented some response to the impingement stimulus.

\section{Operatory technique - Group B}

After reaching the anesthetic plane, a supra-umbilical median laparotomy was performed, of approximately three centimeters, identifying and exteriorizing the duodenum.

At approximately one centimeter distally to the mouth of the common hepatic duct, a segment of the duodenum of approximately three centimeters was isolated between two bull dog clamps.

With the help of a surgical microscope, in a 10-fold magnification, two punctures were done on the antimesenteric border of the loop, with a $21 \mathrm{G}$ (GAUGE) needle, separated eight millimeters from one another. The distance was measured with a compass in the desired opening. The duodenal wound was completed by bringing together the two puncture points, with microsurgical scissors, the interest being on all the layers of the loop, with exposure of the intestinal lumen (Figure 1).

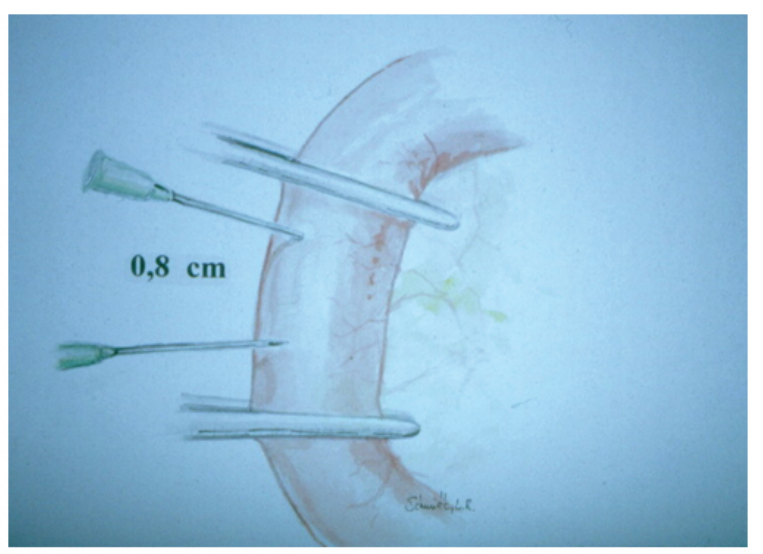

FIGURE 1 - Isolated duodenal segment, with evidence of the two punctures on the antimesenteric border, separated by $8 \mathrm{~mm}$

Under microscopy, in a 16-fold magnification, the patch of amniotic membrane with an elliptical shape was sutured to the edges of the duodenotomy. Initially, it was repaired with 4 cardinal points, with a 7.0 polypropylene wire. The fixation being completed with total continuous suture, clockwise, starting at the 12 hour, with a pre-mounted cylindrical needle using the same wire. After the suture and the removal of the repairs and clamps, the duodenum was repositioned in the peritoneal cavity (Figure 2).

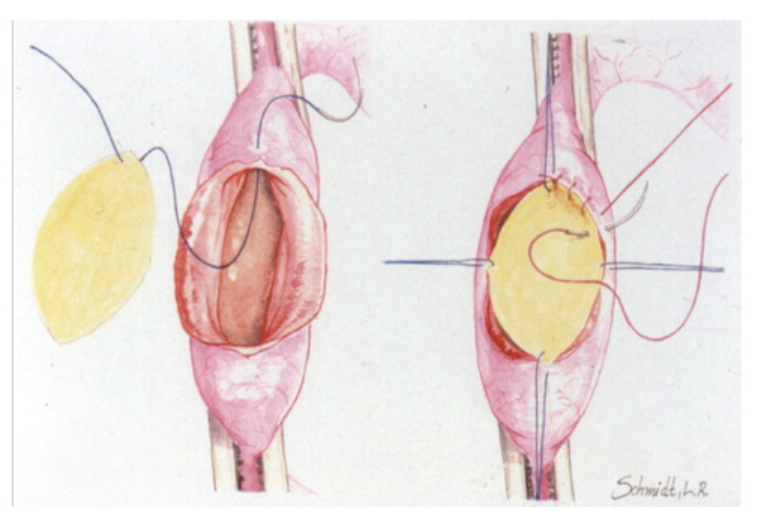

FIGURE 2 - Amniotic membrane patch technique 
The abdominal wall synthesis was done in two planes. Once the operation was finished, all animals stayed in a heated environment at 37.5 degrees centigrades, until they were able to move freely.

\section{Operatory technique - Group A}

The technique used on the animals in Group A was the same as that utilized on Group B. After the wound was created, the loop was placed again in the anatomic position and the abdominal wall was submitted to synthesis.

The animals were examined during their anesthetic recovery in daily visits, until it was time for euthanasia and the findings being recorded in a specific protocol.

In the post operatory period, the wound was observed in a daily basis to check for hemorrhage, wound dehiscence and infection, as well as edema on the back limbs.

\section{Macroscopic assessment}

\section{$\underline{\text { Group A }}$}

The animals in Group A were re-operated on in postoperatory periods of $1,3,5,7,14,21$ and 28 days, utilizing the same anesthetic technique that was used in the operations.

\section{Group B}

The post-operatory outcome was observed in Group B. In case of death, the animals were submitted to necropsy.

\section{Re-operation technique}

The anesthesia was the same used in the implant procedure of the amniotic membrane patch on the duodenum.

The access route to the peritoneal cavity was a broad incision in an inverted "U"shape, starting on the left iliac fossa, around the back and ending on the right iliac fossa, with the purpose to keep any possible parietal adherences whole. An inventory of the peritoneal cavity was conducted, with special attention being paid to adherences, suture dehiscence, fistula formation and infection.

The duodenum was identified and mobilized, for the resection of a segment of approximately $2 \mathrm{~cm}$, in a block, the inside of which contained the region on which the amniotic membrane patch was implanted. The macroscopic findings were recorded.

After being fixed in an aqueous solution of formol at $10 \%$, it was sent to the Pathological Anatomy Laboratory of the UFSC University Hospital, for histological analysis.

\section{Adherences}

Whenever possible, the histological structures which adhered to the region of the duodenal repair were recorded. Results

The results obtained were based on the analysis of the animals' clinical outcome, on macroscopic findings of the reoperations and on the histological analysis of the surgical specimen.

\section{Clinical outcome}

\section{Group A}

The animals in group A developed abdominal distension, accompanied by a progressive reduction in their mobility and all died within 13 to 19 hours after operation, with a mean time of approximately 17 hours.

\section{Group B}

No deaths were observed and there were few clinical complications. Two animals in Group B1 developed intestinal obstruction and abdominal distension. One animal in Group B3 developed infection and dehyscence of some stitches positioned on the skin. In Group B28, one animal developed an incisional hernia on the second post-operatory day, yet reduceable and non-complicated.

\section{Macroscopic assessment}

\section{Group A}

Upon macroscopic assessment, during necropsy, the development of peritonitis was observed. It was also observed that the provoked wounds remained open.

\section{Group B}

Upon assessment of the peritoneal cavity, there was evidence of parietal adherences on many animals. The animal with the incisional hernia presented partial dehiscence of the aponeurotic muscle plane suture and adherence of the greater omentum to the hernial sac. On one animal from Group B7 and another from Group B14 parietal adherences of the greater omentum were observed and four other animals presented adherence of the meso-seminal vesicle to the peritoneal face of the abdominal wall suture (Table 1).

TABLE 1 - Group B. Structures adhered to the AM patch location in the duodenum

\begin{tabular}{lcc}
\hline Adhered Structures & $\mathbf{N}$ & $\mathbf{\%}$ \\
Jejunal loop & 17 & 22.67 \\
Colon & 14 & 18.67 \\
Liver & 14 & 18.67 \\
Parietal peritonium & 14 & 18.67 \\
Fat tissue & 09 & 12.00 \\
Meso-seminal vesicle & 04 & 5.33 \\
Duodenum & 02 & 2.67 \\
Ileal loop & 01 & 1.32 \\
\hline Total & $\mathbf{7 5}$ & $\mathbf{1 0 0}$ \\
\hline
\end{tabular}

One animal euthanized on the 28th day post-op presented an abscess on the right iliac fossa, measuring approximately $1 \mathrm{~cm}$ on its greater axis, with a loop from the ileum adhered to its wall. The two animals with abdominal distension in Subgroup B1 presented gastrointestinal dilation due to duodenal obstruction, one located in the region of the patch and the other $1 \mathrm{~cm}$ distal from it. The rest of the animals presented a normal peritoneal cavity examination.

Upon examination of the region surrounding the amniotic membrane patch in the duodenum adherences could be seen on all of the animals in Group B. The animals in subgroups B1 and B3 had a blockage of the region determined by loose adherences, with fibrin deposits that were easily undone by means of blunt dissection. In the other groups the adherences were more firm, with no fibrin deposits and presented significant hemorrhage when cut for removal of the surgical specimen (Table 2). 
TABLE 2 - Location of the amniotic membrane patch in Group B animals

\begin{tabular}{|c|c|c|c|c|c|c|c|c|}
\hline Location & B1 & B3 & B5 & B7 & B14 & B21 & B28 & TOTAL \\
\hline of $\mathbf{A M}$ & N \% & $\mathbf{N} \%$ & N \% & $\mathbf{N} \%$ & $\mathbf{N} \%$ & N \% & N \% & $\mathbf{N} \quad \%$ \\
\hline On the wall & $6 \quad 100$ & $\begin{array}{ll}6 & 100\end{array}$ & $6 \quad 100$ & 116.7 & $0 \quad 0$ & $0 \quad 0$ & 0 & 1945.2 \\
\hline In the lumen & 0 & 0 & $0 \quad 0$ & 583.3 & 233.3 & 0 & 0 & $\begin{array}{ll}7 & 16.7\end{array}$ \\
\hline Absent & 0 & 0 & 0 & $0 \quad 0$ & 466.7 & 6100 & 6100 & 1638.1 \\
\hline Total & 6100 & 6100 & 6100 & $\begin{array}{ll}6100 \\
\end{array}$ & $\begin{array}{lll}6 & 100 \\
\end{array}$ & 6 100- & $\begin{array}{ll}6100 \\
\end{array}$ & $\begin{array}{ll}42 \quad 100 \\
\end{array}$ \\
\hline
\end{tabular}

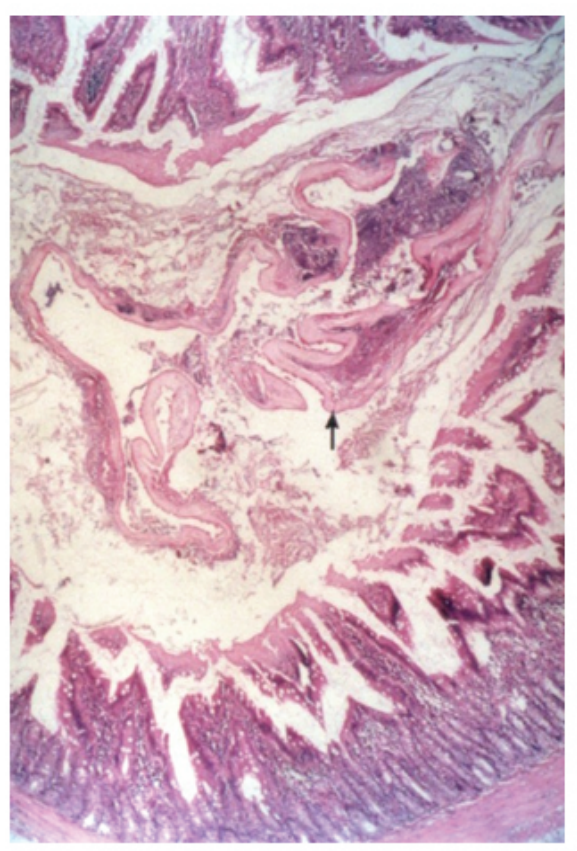

FIGURE 3 - Free amniotic membrane in intestinal lumen

\section{Discussion}

The amniotic membrane presents characteristics which one would hope to find in an ideal bioprosthesis: it is easy to obtain, has a low cost, little antigenic, has an anti-bacterial activity, can be stocked, allows epithelial growth when used in the digestive tube, and its nutrition through diffusion allows it to be used as a free graft $^{15}$.

In the trial described herein, the amniotic membrane was fixed in glutaraldehyde. According to Norris, this fixation promotes interconnections of the five dialdehyde carbons in the drug with the amniotic protein, thus promoting a significant increase in the material's tensile strength, with no changes observed in its chemical structure or thickness, aside from increasing the storage time ${ }^{10}$. The membrane provided enough strength to enable surgical handling, due to its histological structure, especially the compact matrix layer ${ }^{16}$.

The duodenum of an adult Wistar rat measures approximately ten centimeters in length lucianoand three millimeters in diameter.

Epithelization

TABLE 3 - Distribution of animals according to the epithelization status of the duodenal wound repair region in Group B

\begin{tabular}{|c|c|c|c|c|c|c|c|c|}
\hline Epithelization & B1 & B3 & B5 & B7 & B14 & B21 & B28 & Total \\
\hline & N $\%$ & N $\%$ & N \% & N $\%$ & $\mathbf{N} \%$ & $\mathbf{N} \%$ & N \% & $\mathbf{N} \%$ \\
\hline Absent & $6 \quad 100$ & $\begin{array}{ll}5 & 83.3\end{array}$ & 466.7 & 233.3 & 00 & 00 & 0 & 1740.5 \\
\hline Early & $0 \quad 0$ & $\begin{array}{ll}1 & 16.7\end{array}$ & 233.3 & 350.0 & $0 \quad 0$ & 0 & 0 & $\begin{array}{ll}6 & 14.3\end{array}$ \\
\hline Intermediate & 0 & 00 & $0 \quad 0$ & 116.7 & 350.0 & $0 \quad 0$ & 0 & $\begin{array}{ll}4 & 9.5\end{array}$ \\
\hline Advanced & 0 & 0 & 0 & $0 \quad 0$ & 350.0 & 350.0 & 0 & $\begin{array}{ll}6 & 14.3\end{array}$ \\
\hline Complete & 0 & 0 & 0 & 0 & $0 \quad 0$ & 350.0 & 6100 & 921.4 \\
\hline Total & $\begin{array}{ll}6 & 100\end{array}$ & 6100 & 6100 & 6100 & 6100 & 6100 & $\begin{array}{ll}6 & 100\end{array}$ & 42100 \\
\hline
\end{tabular}

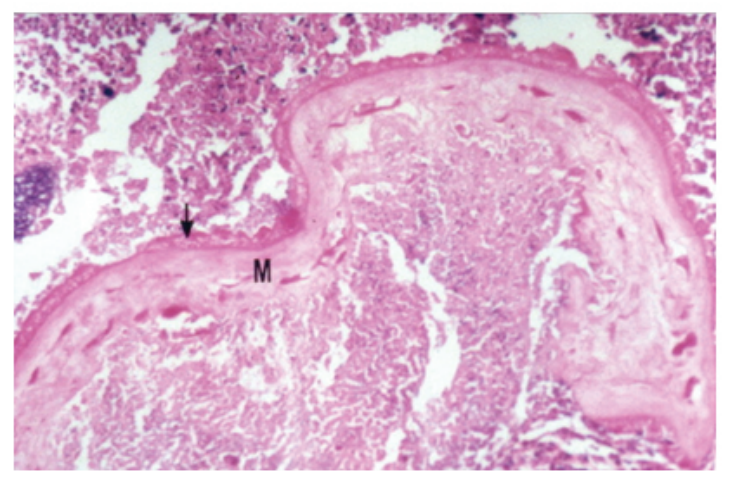

FIGURE 4 - Demonstrates epithelization over the amniotic membrane (AM)
Thus, the duodenal wound of eight millimeters in length, created longitudinally on the antimesentheric border of the duodenum was severe enough to provoke death in the non-treated animals, as occurred in Group A, and technically speaking, allowed for the implant of the amniotic membrane patch, as occurred in Group B.

All animals in the control group died. Upon microscopy, signs of peritonitis were observed, and the duodenal wound remained open.

The most frequent clinical complications of the operations to treat the duodenal wounds were suture dehiscence with fistula formation and intestinal obstruction ${ }^{3,5}$. 
TABLE 4 - Distribution of animals in Group B, according to the regeneration status of the muscle layer in the duodenal wound region

\begin{tabular}{|c|c|c|c|c|c|c|c|c|}
\hline Repair & B1 & B3 & B5 & B7 & B14 & B21 & B28 & TOTAL \\
\hline Muscle & $\mathbf{N}^{\circ} \%$ & $\mathrm{~N}^{\mathbf{0}} \%$ & $\mathrm{~N}^{\circ} \%$ & $\mathbf{N}^{\mathbf{0}} \%$ & $\mathbf{N}^{\mathbf{0}} \%$ & $\mathbf{N}^{\mathbf{0}} \%$ & $\mathrm{~N}^{\mathbf{0}} \%$ & $\mathbf{N}^{\mathbf{0}} \%$ \\
\hline Discontinued & 6100 & 6100 & 6100 & 583.3 & $0 \quad 0$ & $0 \quad 0$ & $0 \quad 0$ & 2354.8 \\
\hline Partial & $0 \quad 0$ & $0 \quad 0$ & $0 \quad 0$ & 116.7 & 6100 & 0 & 0 & 716.7 \\
\hline Advanced & 0 & 0 & 0 & $\begin{array}{ll}0 & 0\end{array}$ & $0 \quad 0$ & 466.7 & $0 \quad 0$ & $4 \quad 9.5$ \\
\hline Complete & 0 & 0 & 0 & 0 & 0 & 233.3 & 6100 & 819.0 \\
\hline Total & 6100 & 6100 & 6100 & 6100 & 100 & 100 & 100 & 100 \\
\hline
\end{tabular}

In Group B, obstruction of the intestinal lumen was observed in two animals, one due to a clot and the other due to the angulation and adherence of the intestinal loop. No fistula formation was observed.

The formation of adherences following surgical interventions in the peritoneal cavity is frequent. It is postulated that adherences take place following the lesion of a serous surface due to the release of an exsudate which is rich in fibrinogen with a subsequent fibrin deposit, the organization of which causes one surface to be fixed to the other. In this context, it was decided to use the epithelial face of the amniotic membrane turned to the abdominal cavity, so as to reduce the formation of adherences ${ }^{8}$.

Despite the adopted management technique, all animals in Group B presented adherences of the patch location to the structures in the peritoneal cavity, thus suggesting the existence of other causes for this phenomenon, which can only be explained through new experiments.

Barlas, in the terminal ileum of rabbits, observed that the amniotic membrane remained in the repaired intestinal wall and the newly-formed epithelium grew over it ${ }^{13}$. When it was used to repair lesions in the colon of rats, Mello observed that, within one postoperatory week the human amniotic membrane was necrotized and fixed to the edges of the colon wounds by the suture stitches ${ }^{6}$. However, in the other histological controls used with only four and 12-week post-operatory periods, the amniotic membrane was not identified and its final destination not being clarified in detail ${ }^{3}$.

In the Group B animals, the amniotic membrane underwent progressive degeneration, both of the epithelium as well as of the matrix, until, around the seventh day post-operatory, it was eliminated to the lumen of the duodenum (Table 2 and Figure 3 ). This fact is unique, considering the behavior of the human amniotic membrane, when used as a patch, on other types of tissue.

The amniotic membrane is considered to be a material of low antigenic potential ${ }^{15}$.

In the animals studied, the histological results obtained did not express a process of immunological rejection of the host against the amniotic membrane.
On the external face of the amniotic membrane patch, a response of the organism against the patch occurred, similarly to the physiological repair. The acute inflammatory infiltrate, intense at first, gradually decreased as the post-operatory period progressed, and the chronic inflammatory infiltrate presented an opposite behavior, although it began to decrease in the most advanced post-operatory periods. This response was similar to a physiological response to aggression in rats, when it comes to the time and the intensity of the inflammatory response.

The mucous epithelium which coats the intestine is comprised of labile cells which have the characteristic of proliferating continuously. In the case of cell lesion or cell loss, the regeneration of the epithelium, partial or total, takes place thanks to the proliferation of the remnant cells, in a centripetal fashion. The human amniotic membrane, when used as a patch in the terminal ileum of rabbits, allowed for the growth of the newly-formed epithelium over its surface. Initially the epithelium was formed by a single layer of cells which matured with the subsequent development of normal villi ${ }^{13}$.

Something similar was observed when the amniotic membrane was used, in the same way, for the treatment of colon wounds in rats. In the Group B animals, the epithelization of the duodenal wall repair region took place in a progressive way, in a centripetal fashion (Table 3 and Figure 4). However, epithelial growth did not occur over the patch surface, but over the granulation tissue developed externally to the amniotic membrane.

The regeneration of the muscle layer occurred through the progressive replacement of collagen by muscle fiber. Mello observed that the muscle fibers on the edge of the colon wound progressed to reconstitute the muscle layer, though with a certain disarrangement as to the fiber layout, yet without the formation of a stenotic scar ${ }^{6}$.

In Group B, the histological analysis showed a fully discontinued smooth muscle layer in the first post-operatory days, and a complete smooth muscle layer at 28 days.

Upon analysis, the amniotic membrane proved to be a biological tissue which served as a temporary "seal" of the provoked 
lesion and allowed for second-intention healing with the reestablishment of the duodenal wall structure.

\section{Conclusions}

The amniotic membrane served as a temporary seal of the provoked lesion and allowed the duodenal wall structure to heal by second-intention.

The amniotic membrane underwent degenerative changes in the matrix and in the epithelium until the seventh post-operatory day, when it was eliminated to the duodenal lumen.

\section{References}

1. Carrillo EH, Richardson JD, Miller FB. Evolution in the management

2. Donovan AJ, Hagen WE. Traumatic perforation of the duodenum. Am J Surg. 1966;111:341-50.

3. Flint LN, McCoy M, Richardson D, Pouk HC. Duodenal injury: analysis of common misconceptions in diagnosis and treatment. Ann Surg. 1980;191:697-702.

4. Ivatury RR, Nassoura ZE, Simon RJ, Rodriguez A. Complex duodenal injuries. Surg Clin North Am. 1996;76:797-812.

5. Asensio JA, Feliciano DV, Britt LD, Kerstein MD. Menagement of duodenal injuries. Curr Probl Surg. 1993;11:1021-3.

6. Mello CMG, Maia FJS, Accetta I, Palombo A, Lima HS, Caparica AF, Silva MAG. Uso da membrana amniótica humana como enxerto biológico em feridas do cólon direito: estudo experimental em ratos. Rev Col Bras Cir. 1994;21:65-70. of duodenal injuries. J Trauma. 2007;40:1037-46.

7. Bocig AG, Pblete AJ, Munita BJ, Korn BO, Guinez GR, Urrutia ML, Valenzuela GJ, Vial LM. Penetrating abdominal stab-shape wounds. Rev Chil Cir. 1994;46:404-9.

8. Papachristou DN, Fortner JG. Reconstruction of duodenal wall defects with the use of a gastric "island" flap. Arch Surg. 1977;112:199-200.

9. Pigeon J. Treatment of second-degree burns with amniotic membranes. Can Med Assoc J. 1972;72:315-22.

10. Gharib M. Repair of prenataly ruptured omphalocele and the paraumbilical abdominal wall defect with the infant's own fetal membranes. Munch Med Wochenschr. 1975;117:1555-8.

11. Seashore JH, MacNaughton RJ, Talbert JR. Treatment of gastroschisis and omphalocele with biological dressings. J Pediatr Surg. 1975;10:9-17.

12. Massee JS, Symmonds RF, Dockert MB, Gallenback GA. Use of fetal membranes a replacement for pelvic peritoneum after pelvic exenteration in the dog. Gynecol Obstet. 1962;13:407-11.

13. Barlas M, Gokçora H, Erekul S, Dindar H, Yucesan S. Human amniotic membrane as an intestinal patch for neomucosal growth in the rabbit model. J Pediatr Surg. 1992;27:597-601.

14. Cukingnan RA, Culliford AT, Worth MH. Surgical correction of a lateral duodenal fistula with the roux-y technique: report of a case. $\mathrm{J}$ Trauma. 1975;15:519-23.

15. Akle CA, Adinolfi M, Welsh KI, Leibowitz S. Immunogenicity of human amniotic epithelial cells after transplantation into volunteers. Lancet. 1981;2:1003-5.

16. Saa ES, Larrain ER, Ross M, Raddatz AE, Reyes J, Diaz A, Espindola M. Gun abdominal wound: surgical treatment. Rev Chil Cir. 1990;42:3214.

Conflict of interest: none Financial source: none

\section{Correspondence:}

Armando José d'Acampora

Condomínio San Diego, casa 9

88034-420 Florianópolis - SC Brazil

Received: August 26, 2009

Review: October 20, 2009

Accepted: November 18, 2009

\section{How to cite this article}

Schimidt LR, Cardoso EJ, Schimidt RR, Back A, Schiazawa MB, d'Acampora AJ, de Sousa MV. Silva W, Fagundes DJ, Seidel AC, Taha MO. The use of amniotic membrane in the repair of duodenal wounds in Wistar rats. Acta Cir Bras. [serial on the Internet] 2010 JanFeb;25(1). Available from URL: http://www.scielo.br/acb 